\begin{tabular}{l} 
Dr Nelladee McLeod \\
Palane \\
University of Pretoria \\
nelladee.palane@up.ac.za \\
\hline Prof Sarah Howie \\
University of Stellenbosch \\
sarahhowie@sun.ac.za \\
\hline DOI: http://dx.doi. \\
org/10.18820/2519593X/pie. \\
v37i1.4 \\
ISSN 0258-2236 \\
e-ISSN 2519-593X \\
Perspectives in Education \\
$201937(1): 43-57$
\end{tabular}

Date Published: February 2020

\section{A comparison of higher- order reading comprehension performance for different language of instruction models in South African primary schools}

\begin{abstract}
In this article, preProgress in Reading Literacy Study (prePIRLS) 2011 data is used to compare the performance of different language of instruction groupings (English, Afrikaans and African languages) in primary schools on the more complex, higher-order reading comprehension items tested in a large-scale international test. PrePIRLS 2011 ( $N=15$ 744) was conducted in South Africa's eleven official languages. Schools were sampled according to the language of learning and teaching (LoLT) in Grades 1-3 and the reading comprehension test was administered in that same language. To examine bilingual effects, a sub-sample was drawn from the national dataset that consisted of low socio-economic status (SES) learners whose first language was not English (but who had received instruction in English from grades 1-3) as well as Iow SES learners who received their Foundation Phase instruction in one of the African languages as a mother tongue.
\end{abstract}

A linear regression ( $n=6342$ ) showed that low socio-economic status (SES) learners whose language of instruction is English, despite it not being their mother tongue, benefitted by 20.35 score points with a t-value of 3.19. This is significant at the 0,01 level (equivalent to half a year) from being in the English $L 2$ group, in comparison to the African languages $L 1$ group, as a measure of achievement on the higher-order subscale.

It is argued in this paper that learners whose LoLT is English, but who do not speak English as a home language and tend to be part of the most disadvantaged sector of the population, perform better on the higher-level reading comprehension processes when compared with African language mother tongue instruction across the same grades and socio-economic status. The findings highlight the importance of improved English second language instruction for all LoLT groupings.

Keywords: English L2, higher-order reading comprehension, mother tongue, language in education

\section{Introduction}

An adequate reading comprehension level is a critical factor in determining overall learning achievement. Moreover, weak reading comprehension prevents the learner from reaching a required threshold necessary for the ability to comprehend abstract, academic text requiring higher-order 
reading comprehension (Cummins, 2000). According to Cummins (1979), if learners have developed a sound understanding of their first language, these skills will be transferred to the additional (L2) language that is introduced later. He argues that in bilingual education systems, it is important for learners to develop strong literacy skills in their home language as a basis for building academic literacy proficiency that can be shared across languages (Cummins, $1979,2000)$. This research integrates theory that emphasises the importance of the home and school context in learning (Bandura, 2001; Bruner, 1996; Vygotsky, 1978) with Cummins' (1979) work on bilingual development and Bourdieu's (1986) writing on cultural capital as a research lens for interrogating the low level of reading comprehension performance observed in the preProgress in Reading Literacy Study (prePIRLS) 2011 (Howie et al., 2012).

In grade 4, most South African learners transition to English as their language of learning and teaching (LoLT) in the classroom. However, evidence that the learners have not reached a higher level of language threshold development in their home language is seen in the extremely low achievement performance found for grade 4 learners in the prePIRLS 2011 study. Results from the prePIRLS 2011 study, conducted at Year 4 level internationally across 60 countries and in South Africa in the 11 official languages, reveal the lowest reading achievement score in comparison with the international centre point of 500 (Mullis \& Martin, 2012).

Historically African language learners have been required to learn in an African language for their primary schooling in South Africa. Officially, this meant they were to receive mother tongue education in their primary years, but change to English or Afrikaans as their LoLT in secondary school. The Department of Basic Education's report (2010) on the Language of Learning and Teaching indicated that $76 \%$ of African learners were learning in their home languages in the Foundation Phase in 2007. However, according to Pretorius and Mampuru (2007), the majority of learners on the African continent do not have the advantage of being able to do all or even some of their schooling in their home language. In the current South African context, schools and classrooms are often diverse linguistic environments and the languages may be mixed in spoken language (Probyn, 2009). However, Pretorius (2014) notes that the prePIRLS results indicate that reading is more than simply a language issue and should be explicitly taught and nurtured since, despite the LoLT being the home language for most learners, reading proficiency was still extremely low.

Learners who have been taught in their home language from grades 1-3 often begin, from grade 4, to receive classroom instruction in the additional language, which is usually English. The performance of the learners in the 2006 and 2011 study reveal that they are not well prepared for the literacy challenges moving into a new phase (Zimmerman, 2010; Pretorius, 2014) where there is a language change as well as a focus change and where learning to read in the Foundation Phase becomes reading to learn in the Intermediate Phase. Research has shown that poor comprehension in a mother tongue affects transfer of linguistic competence to the additional language, yet in the South African context, learners are, nonetheless, required to perform cognitively complex tasks in the additional language, namely English, from the grade 4 level.

Endorsement of bilingual transitional models, where development in the mother tongue is regarded as a prerequisite for developing proficiency in an additional language, is pervasive in the literature (Banda, 2000; Cummins, 1992; Taylor \& Coetzee, 2013). Some proponents of this theory argue that the interdependence of literacy skills across languages takes at least five years to master (Cummins, 1992). Others state that it takes between six to eight years to 
learn enough of a second language in formal school environments before this language can be used as a medium of instruction (Reeves et al., 2008). Taylor and Coetzee (2013) demonstrate that home language instruction in the early years of schooling significantly improves English acquisition in later grades. They, however, point out that given certain contextual factors, English instruction from grade 1 may be preferable and schools should make the choice between mother tongue instruction and an immersion approach (Taylor \& Coetzee, 2013).

The requirement that learners be schooled in their mother tongue during the years of apartheid has, among other reasons, resulted in a backlash amongst the African population, with the result that nowadays, with greater access to schooling in English, many families prefer this route for their children. The reason is the perception that schooling in English LoLT will lead to fluency in English and create opportunities for social mobility. Learners receiving instruction in a mother tongue other than English still receive language lessons in English as a subject (usually as a first additional language). However, these lessons are not always of the quality or quantity that would result in the fluency level necessary for higher-order reading comprehension. The fact that learners must all move to English tuition in grade 4 makes the need for high quality, explicit instruction in English as a second language in the Foundation Phase and throughout the learner's school career a critical requirement.

Mother tongue instruction throughout schooling for all learners in South Africa is observed as an educational and political ideal in a complex multilingual context where, nonetheless, fluency in the additional language (for many South African learners) is seen as a vehicle of social mobility and a means of reaping tangible socio-economic benefits (Posel \& Casale, 2011). As such, it becomes necessary to weigh up the multiplicity of factors affecting the learner's future well-being, not least of which is the need for careful, timeous preparation for the National Senior Certificate in grade 12, which is written in either English or Afrikaans. Of interest, is that Pretorius and Mampuru (2007) have noted that most learners in Africa complete their schooling in the former colonial language of that country.

Concrete and nuanced factors affect and mediate the efficacy of mother tongue instruction for African language learners in South Africa. Critical questions need to be asked around issues such as:

- how homogenous the language of the school or area is which determines whether the learner will indeed be instructed in a mother tongue or in another African language predominant in the area or chosen by the school itself; or

- the availability of reading and textbook resources in the mother-tongue; and

- the language in which the teachers have been trained and their fluency levels as well as an ability to convey complex concepts to a class.

Access to mother tongue education is enshrined in the South African Constitution, which obligates the state to provide each person with education in the language of his or her choice wherever possible. While the state is required to consider quality, equity and redress when providing education, this objective must be weighed against the limitation of resources. In South Africa, it has been found that particularly amongst better educated black parents, it is recognised that the home language must be nurtured, even while there is strong support for English only (Evans \& Cleghorn, 2014). Despite the Constitution deeming all eleven languages to be of equal value and parents (as represented by a democratically elected school governing body) having the power to choose the language of instruction in schools, many parents, nonetheless, prioritise English instruction (Woolman \& Fleisch, 2006). 
Banda (2009) argues that current policy is based on Western and colonial notions of multilingualism and that the promotion of multilingualism in South Africa should not be a case of promoting eleven monolingual streams of distinctive languages in homogenous speech communities, since this perception is erroneous. Banda (2009) further posits that even though the country has eleven official languages, the majority of Africans speak either Nguni or Tswana-Sotho dialects, or that careful planning and cross-linguistic referencing would enable these languages to share a large amount of teaching and reading material. Given the extent to which language in schools often becomes a melting pot of the dialects spoken in the area, and the classroom the interface of more than one language, these ideas should be explored further. This approach could address the reality of financial and capacity constraints while taking cognisance of the socio-cultural call for indigenous languages in schools. It also offers some leeway for the possibility of realising a bilingual 'late-exit' approach, where the number of years of instruction in the home language is extended. Similarly, pragmatism also needs to be foregrounded in the provision of pedagogically sound and consistent early English L2 instruction since so many South Africans regard English as essential for their children to find their way into global participation.

It is argued in this paper that learners whose LoLT is English, but who do not speak English as a home language, and tend to be part of the most disadvantaged sector of South Africa, perform better on the higher-level reading comprehension processes, when compared with African languages mother tongue instruction across the same grades and socio-economic status (SES). The primary research objective is a comparison of performance on the higherorder reading comprehension items for the language of instruction groupings English, Afrikaans and African languages. The group "African Languages" includes isiZulu, isiNdebele, Sepedi, Setswana, Xitsonga, isiXhosa, Tshivenda, siSwati and Sesotho.

PrePIRLS 2011 data was used to compare the performance of the different language of instruction groupings on the more complex, higher-order reading comprehension items tested in the large-scale international test. Since prePIRLS 2011 sampled schools according to the language of instruction of the school (also referred to as Language of Learning and Teaching or LoLT), the language of instruction of the learner is also the language of the test (LoT).

Performance is compared across these three groups for learners who spoke the language of the test before school and those who did not. Performance is then compared for the African Languages home language/L1 grouping and the English L2 learners. Learners who did not speak the language of the test before school and wrote in English, are compared to the learners who wrote in an African language and did speak the language of the test before school.

The analysis for this paper is conducted at the learner level (single-level analyses) and learners whose LoT/LoLT is English as an L2 but may be in a school where they find themselves amongst peers who are mostly English first language speaking or the school may be predominantly English second language speaking.

\section{Methodology for prePIRLS 2011}

In 2011, 15744 grade 4 learners in 341 schools across all provinces participated in the prePIRLS assessments in the language that was their LoLT during the Foundation Phase of grades 1-3. All eleven official languages of South Africa were tested. Permission to conduct the prePIRLS 2011 study in the sampled schools was obtained from the Minister of Education, school principals, teachers and parents, and ethical clearance was obtained 
from the University of Pretoria. For secondary analysis of the data, ethical clearance was obtained from the University of Pretoria. The prePIRLS reading comprehension assessment is based on shorter texts comprising more accessible vocabulary than the international PIRLS assessments intended for grade 4 .

\section{Sampling}

A three-stage stratified cluster sampling design was employed in prePIRLS 2011. In South Africa, a sample of schools that went up to grade 4 level was selected. The sample was stratified explicitly by language. Originally 345 schools were sampled, but only $341(99.1 \%)$ were eligible for participation. In each school, an intact class was sampled and all the learners present on the day of testing were included.

The majority of learners $(71 \%)(n=14030)$ wrote the prePIRLS test in their home language (mother tongue). However, for the learners writing in English, approximately $70 \%$ were not mother tongue English speakers.

\section{Design of the instruments}

The design of the instruments included the testing of reading comprehension of literary and informational text. Item design incorporated constructed response and multiple choice type questions.

Questions accompanying each prePIRLS reading text were designed to assess learner reading ability in the following reading comprehension processes:

Focus on and retrieve explicitly stated information included tasks where the learner had to identify information explicitly stated in the text: 57 items, which were $45 \%$ of the score points.

Make straightforward inferences included tasks such as having to infer that one event caused another event: 35 items and correspondingly $27 \%$ of the score points.

Interpret and integrate ideas and information included reading tasks where the learner had to discern the overall message or theme of a text, infer a story's mood or tone and interpret a real-world application of text information: 17 items.

Evaluate and examine content, language and textual elements included reading tasks such as a description of how the author devised a surprise ending, judging the clarity of information in a text and determining an author's perspective on the central topic: 14 items. Items measuring the ability to interpret and integrate ideas totalled $28 \%$ of the score points.

Interpreting and integrating and examining and evaluating are both higher-level comprehension processes and the PIRLS reporting strategy combines these items into a single subscale in order to provide a stable measure of higher-order reading comprehension for the prePIRLS assessment (Mullis, 2007).

\section{Description of the international benchmarks of reading achievement}

The benchmarks are a qualitative description of learner performance at different levels in order to describe competencies at each of the set scores. The range of performance shown by learners is represented by four benchmarks: Advanced (625 points), High (550 points), Intermediate (475 points) and Low (400 points). The descriptions of each are cumulative, 
meaning that learners who were able to reach the higher benchmarks could also demonstrate knowledge and skills associated with the lower ones.

\section{Discussion of the results}

In the 2011 PIRLS study, 15744 learners in 341 schools across all the provinces were tested in the 11 official languages using the prePIRLS assessment. The mean score for South African learners was 461, well below the international centre point of 500 (Howie et al., 2012). In most languages, the achievement was significantly higher when children wrote in their home language, with the exception of Afrikaans, isiZulu and Sepedi, where there was no significant difference. Those writing prePIRLS in English, who did not have English as a home language, achieved 80 points less than those who did (Howie et al., 2012).

The results of the research conducted for this study are discussed in Sections 3.1-3.5 below.

\section{A Comparison of learner performance across languages of instruction}

Descriptives were run using the IDB Analyser (version 3.0) and are presented in Table 1 below, which illustrates the difference in mean performance for learners who spoke the language of the test before starting school.

Table 1: Language of test/spoke the language before school: Comparing learner mean performance

\begin{tabular}{|l|l|l|l|l|l|l|}
\hline $\mathbf{w}$ & $\begin{array}{l}\text { Spoke } \\
\text { LoT } \\
\text { before } \\
\text { school }\end{array}$ & $\begin{array}{l}\text { Sample } \\
\text { size (n) }\end{array}$ & $\begin{array}{l}\text { Per } \\
\text { cent }\end{array}$ & $\begin{array}{l}\text { Per } \\
\text { cent } \\
\text { SE }\end{array}$ & $\begin{array}{l}\text { Higher-order } \\
\text { subscale } \\
\text { mean }\end{array}$ & Mean SE \\
\hline Afrikaans & Yes & 1009 & 95,65 & 1,24 & 535,66 & 11,33 \\
\hline & No & 48 & 4,35 & 1,24 & 480,63 & 12,60 \\
\hline English & Yes & 835 & 48,35 & 4,12 & 573,94 & 11,55 \\
\hline & No & 866 & 51,65 & 4,12 & 495,72 & 9,78 \\
\hline $\begin{array}{l}\text { African } \\
\text { Languages }\end{array}$ & Yes & 7705 & 87,77 & 1,07 & 431,01 & 4,42 \\
\hline & No & 1793 & 12,23 & 1,07 & 405,52 & 5,56 \\
\hline
\end{tabular}

The table indicates that mean performance on the higher-order subscale improves where learners spoke the language of the test before going to school for each of these three language groups, but that this difference is more marked for English and Afrikaans. Afrikaans, however, had only 48 learners that wrote the test in Afrikaans but did not speak the LoT before going to school. English had 835 who spoke the language of the test before school and 866 learners who did not. Mean performance on the higher-order subscale for this group is 495.72 $(S E=9.78)$. The African languages group that spoke the language of the test before school $(n=7705)$ has a mean performance of 431.01 ( $S E=4.42)$, showing that on this subscale there is a marked difference between these two groups of learners.

Of particular interest (see shaded groups in Table 1) is the first group comprising the learners who attend school where the LoLT (the same as the LoT as per prePIRLS sampling) is English, but this is not a language they spoke before starting school. The other group are 
the African language learners whose LoLT was an African language from grades $1-3$, but would have transitioned at the start of grade 4 to an English LoLT, but were tested in an African language.

\section{Performance on the international benchmarks for African Languages L1 and English L2}

Almost one out of three South African learners (29\%) was unable to reach the Low International benchmark. Most grade 4 learners $(71 \%)$ reached the Low International benchmark. Forty per cent of the learners also reached the Intermediate International benchmark. Nineteen per cent reached the High International benchmark but only six per cent attained the Advanced International benchmark (Howie et al., 2012).

Mean performance on the international benchmarks is depicted in Table 2 below.

Table 2: Percentage international benchmarks reached by English L2 and African Languages L1

\begin{tabular}{|c|c|c|c|c|c|c|c|c|}
\hline \multirow{2}{*}{ 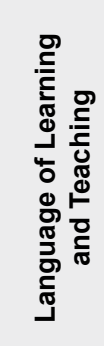 } & \multicolumn{5}{|c|}{$\begin{array}{c}\text { International Reading Scale Benchmark } \\
\text { Reached }\end{array}$} & \multirow{2}{*}{$\begin{array}{c}\begin{array}{c}\text { Higher- } \\
\text { order } \\
\text { subscale }\end{array} \\
\text { Mean }\end{array}$} & \multirow{2}{*}{$\begin{array}{c}\begin{array}{c}\text { Lower- } \\
\text { order } \\
\text { subscale }\end{array} \\
\text { Mean }\end{array}$} & \multirow{2}{*}{$\begin{array}{l}\begin{array}{l}\text { Overall } \\
\text { reading }\end{array} \\
\text { Mean }\end{array}$} \\
\hline & $\begin{array}{l}\text { Below } \\
400\end{array}$ & $\begin{array}{l}\text { At or } \\
\text { above } \\
400, \\
\text { but } \\
\text { below } \\
475\end{array}$ & $\begin{array}{l}\text { At or } \\
\text { above } \\
475, \\
\text { but } \\
\text { below } \\
550\end{array}$ & $\begin{array}{l}\text { At or } \\
\text { above } \\
550 \text {, } \\
\text { but } \\
\text { below } \\
625\end{array}$ & $\begin{array}{l}\text { At or } \\
\text { above } \\
625\end{array}$ & & & \\
\hline 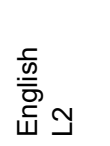 & $20.9 \%$ & $33.1 \%$ & $27.9 \%$ & $14.3 \%$ & $3.9 \%$ & 467.7 & 473.4 & 471.1 \\
\hline 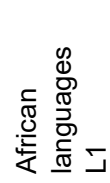 & $37.0 \%$ & $37.3 \%$ & $21.5 \%$ & $4.0 \%$ & $0.3 \%$ & 419.7 & 424.8 & 425.5 \\
\hline
\end{tabular}

The table above shows that in the below 400 points category, a greater percentage of African Languages L1 learners (37.0\%) was placed in this category compared with the English L2 (20.9\%). In contrast, $14.3 \%$ of English L2 learner achievement placed them in the "at or above 550, but below 625 " category compared with only $4.0 \%$ of African languages L1 learners. The English L2 learner mean is 467.7 score points in contrast to the African languages L1 learner mean score of 424.8 .

\section{Multiple regression comparing the language of instruction models}

The multiple regression tabulated below (Table 3 ) was conducted in the IDB Analyser (version 3.0). There is a 49.55 (t-value significant at -9.06) decrease in score points when the learner writes in English as an L2 (language not spoken before school) compared to an English L1 learner. Notably, the full group of African Language learners achieve 125.18 (t-value significant at 14.03) score points less than the English first language learners. The effect size for this model is moderate at .28 . 
Table 3: Results of a multiple regression comparing language models

\begin{tabular}{|c|c|c|c|c|c|c|c|c|c|c|c|}
\hline \multicolumn{9}{|c|}{ Unstandardised } & \multicolumn{3}{|c|}{ Standardised } \\
\hline $\begin{array}{l}\overline{\mathbf{d}} \\
\bar{\Sigma}\end{array}$ & 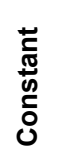 & 岕 & - & 设 & 凹 & B & SE & $\mathrm{t}$ & $\beta$ & SE & $\mathbf{t}$ \\
\hline & 商 & $\begin{array}{l}\hat{\infty} \\
\stackrel{0}{0}\end{array}$ & $\begin{array}{l}\frac{J}{i} \\
\dot{i}\end{array}$ & $\stackrel{\infty}{\sim}$ & đo. & & & & & & \\
\hline $\begin{array}{l}\frac{\bar{\omega}}{\bar{\sigma}} \\
\frac{\bar{w}}{\tilde{W}} \\
\text { บ }\end{array}$ & & & & & & -49.55 * * & 5.85 & -8.48 & $-.20^{* *}$ & -.02 & -9.06 \\
\hline 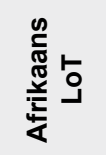 & & & & & & -23.72 & 14.44 & -1.64 & -.07 & .04 & -1.66 \\
\hline ڤ్ & & & & & & $-125.18^{\star *}$ & 11.36 & -11.02 & $-.59^{\star *}$ & -.04 & -14.03 \\
\hline
\end{tabular}

${ }^{*} t$-value $>1.96{ }^{* *} t$-value $>2.58$

\section{Comparing African Languages L1 and English LLow SES learner performance}

The next step in this research was a comparison across two language groups sampling learners from a low socio-economic stratum for achievement on the prePIRLS 2011 higherorder subscale that combines interpreting and integrating items and examining and evaluating items. This research investigated whether belonging to either the non-mother tongue English LoLT (low SES) group or the African Languages LoLT as equal to mother tongue (low SES) group results in a significantly improved chance of performing better on the higherorder prePIRLS 2011 subscale. Further analysis also used performance on the High and Advanced International Benchmarks as a demonstration of proficiency in higher-order reading comprehension. The benchmark categories contain items that are not restricted to the higherlevel reading processes, but all the items are formulated in such a way as to require higherorder thinking from the learner. 
The sub-sample derived from the prePIRLS 2011 sample, reflects learners exposed to an English immersion approach, as well as learners comprising the additive bilingual approach to language in education. Afrikaans LoLT learners were not included in this analysis.

Non-mother tongue English learners who wrote in English, and learners writing in the African languages as a mother tongue, with both groups pulled from a low socio-economic background, were isolated through the Learning to Read Survey administered to parents and the School Contextual Questionnaire administered to the principals of the schools tested. Where parents indicated that their children had not spoken the language of the test before school, it was assumed that the language of the test was not their home language. In the School Contextual Questionnaire, where principals indicated that "more than $50 \%$ of the students come from economically disadvantaged homes", this was taken to indicate that the learners falling within this ambit came from low socio-economic backgrounds. A linear regression of the specified sample $(n=6342)$ was conducted with the IEA International Database (IDB) Analyzer software (version 3.0).

Table 4: Linear regression model for language effect on the higher-order subscale

\begin{tabular}{|c|c|c|c|c|c|c|c|c|}
\hline \multirow[b]{2}{*}{$\begin{array}{l}\bar{\Phi} \\
\text { ¿ } \\
\text { ¿ }\end{array}$} & \multirow[b]{2}{*}{ 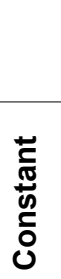 } & \multirow[b]{2}{*}{$\Delta R 2$} & \multicolumn{3}{|c|}{ Unstandardised } & \multicolumn{3}{|c|}{ Standardised } \\
\hline & & & B & SE & $\mathrm{t}$ & $\beta$ & SE & $T$ \\
\hline & 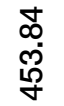 & 0.3 & & & & & & \\
\hline 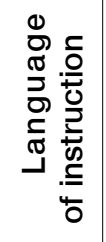 & & & $20.35^{\star \star}$ & 6.38 & 3.19 & $.18^{*}$ & .05 & 3.35 \\
\hline
\end{tabular}

$t$-value $>1.96 ;{ }^{*} t$-value $>2.58$

The linear regression results in Table 4 above reveal that learners from a disadvantaged background, whose LoLT is English, despite it not being a language spoken prior to starting school, benefitted by 20.35 score points $(B=20.35$, t-value $=3.19$ ) by being in the English LoLT group, in comparison to the African languages (LoLT spoken before they started school) group as a measure of achievement on the higher-order subscale.

Since at this point in the analysis, the number of African learners stood at 5858 and the English group at 484, these two groups were made further comparable by randomly selecting 
the same number of African learners as found in the English group. Outliers (a total of eleven selected with SPSS [version 23.0] as being three standard errors above the mean) were removed from the dataset. In this way, the sample size and homogeneity of variance were better equalised.

Once the African Languages L1 group had been reduced for equivalence with the English L2 group ( $n=968)$ and outliers removed, the regression was run again. The results of this regression are depicted in Table 5 below.

Table 5: Linear regression model for language effect of reduced sample on the higher-order subscale

\begin{tabular}{|c|c|c|c|c|c|c|c|c|}
\hline \multirow[b]{2}{*}{$\begin{array}{l}\bar{\Phi} \\
\frac{\delta}{\delta} \\
\Sigma\end{array}$} & \multirow[b]{2}{*}{ 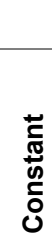 } & \multirow[b]{2}{*}{$\Delta R 2$} & \multicolumn{3}{|c|}{ Unstandardised } & \multicolumn{3}{|c|}{ Standardised } \\
\hline & & & B & SE & $\mathbf{t}$ & $\beta$ & SE & $\mathbf{T}$ \\
\hline & 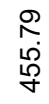 & 0.4 & & & & & & \\
\hline 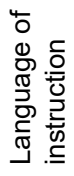 & & & $17.34^{*}$ & 7.13 & 2.43 & $.20^{*}$ & .08 & 2.46 \\
\hline
\end{tabular}

$t$-value $>1.96 ;{ }^{* *} t$-value $>2.58$

Having met all the regression requirements (Field, 2009), the results indicate a 17.34 regression co-efficient $(B=17.34)$ with a t-value of 2.43 , which is significant at the 0.05 level. Learners from a disadvantaged background whose LoLT is English, despite it not being their mother-tongue, benefitted by 17.34 score points (equivalent to just under half a year) from being in the English LoLT group, in comparison to the African languages LoLT group (despite this being their mother tongue) as a measure of achievement on the higher-order subscale.

\section{Comparison of African Languages L1 and English L2 Low SES on benchmarks}

Since items across the achievement booklets are classified according to difficulty levels, aimed at assessing higher-order reading comprehension ability in the high and advanced benchmarks, achievement on this scale is also an indication of learner ability to comprehend text using higher-level processing. By combining benchmarks 4 (550) and 5 (625) as an indication of the highest level of reading comprehension tested and retaining benchmark 3 (475), which includes inferential questions and the more difficult access and retrieve items, a chi square test was conducted to ascertain whether there is an association between LoLT and the likelihood of falling into the highest (combined) benchmark. These analyses are depicted in Tables 6 and 7 below.

Table 6: Language group percentage likelihood of falling into highest level benchmark 


\begin{tabular}{|l|l|l|}
\hline & At or above 475, but below $\mathbf{5 5 0}$ & \multicolumn{1}{|c|}{ At or above $\mathbf{5 5 0}$} \\
\hline $\begin{array}{l}\text { African Languages } \\
\text { L1 }\end{array}$ & $80.7 \%$ & $19.3 \%$ \\
\hline English L2 & $61.4 \%$ & $38.6 \%$ \\
\hline Total & $68.9 \%$ & $31.1 \%$ \\
\hline
\end{tabular}

Table 7: Results of chi-square test for highest level benchmark

\begin{tabular}{|l|l|l|l|l|l|}
\hline & Value & df & $\begin{array}{c}\text { Asymptotic } \\
\text { Significance } \\
\text { (2-sided) }\end{array}$ & $\begin{array}{c}\text { Exact Sig. } \\
\text { (2-sided) }\end{array}$ & $\begin{array}{c}\text { Exact Sig. } \\
\text { (1-sided) }\end{array}$ \\
\hline $\begin{array}{l}\text { Pearson } \\
\text { Chi-Square }\end{array}$ & $14.948 \mathrm{a}$ & 1 & .000 & .000 & .000 \\
\hline $\begin{array}{l}0 \text { cells (.0\%) have } \\
\text { expected count } \\
\text { less than 5. The } \\
\text { minimum expected } \\
\text { count is 43.56. }\end{array}$ & & & & & \\
\hline
\end{tabular}

The association was found to be significant with the results of the chi square test showing that the learners in English non-mother tongue low SES group are statistically more likely to fall in the highest level combined benchmark $\left(X^{2}(1)=14.948, p=.000\right)$ than the African Languages mother tongue low SES group.

\section{Discussion of performance across the different language of instruction groupings}

The above analysis explored how the language group within which the learner falls affected performance on the higher-order and more cognitively complex items in prePIRLS 2011. It was found that across the lowest socio-economic strata, the learners whose LoLT was English for the Foundation Phase of their schooling, performed better than the mother tongue LoLT (African languages group) on the higher-level reading processes assessed in the higher order subscale, and were more likely to be placed in the High and Advanced benchmarks.

Cummins (1979) suggests that the immersion model works better for the middle-class learner (as opposed to the poorer learner) because of access during early childhood to parental re-enforcement of the nature and importance of text (language used in an abstract form and in a manner other than the interpersonal or communicative). This mediation allows for the development of a threshold level of language in the child and the ability to cope with immersion in the additional language. Cummins (1979) stated that the immersion model often does not work well for poorer learners because the home literacy context during early childhood is often inadequate for threshold language development. However, it was found in this study that the immersion group performed better on the higher order items than the additive bilingual group. 
The impact of SES for each of the language of instruction groupings is particularly pertinent to the South African educational context. It is possible that the immersion group (despite having the same low SES home mediatory context experienced by the additive bilingual group with regard to their mother tongue development) has the advantage of a stronger school or classroom mediatory context either through language support or access to text for the learning of English and attaining proficiency in reading comprehension.

\section{Conclusion}

This research examined how the language grouping of learners reflects performance on the higher-order and more cognitively complex items in prePIRLS 2011. It was found that across the lowest socio-economic strata, the learners whose LoLT was English during the Foundation Phase performed better than the mother tongue LoLT African language learners on the higherlevel reading processes assessed in the higher-order subscale.

Differences in performance across language of instruction are indicative of unequal quality of instruction across the languages of instruction. Changing the LoLT does not address the underlying problems, but providing high quality English L2 (alongside quality L1 instruction) from grade 0 is a possible means of addressing inequality.

Learning a home language and learning English as an L2 are both important for the South African learner. English L2 learners perform poorly when compared to English L1 learner performance, despite having had access to English as a LoLT throughout the Foundation Phase. This suggests that English L2 requires a different instructional approach to bring English L2 learners up to the same language proficiency level as their L1 peers, particularly if English is to be the LoLT from grade 4 onwards (McLeod Palane, 2017).

The cultural dominance of English prevalent in South Africa manifests in motivation for parents to have their children instructed in English (de Wet, 2002), a perception of social mobility (Posel \& Casale, 2011) and access to print material in English (Reeves et al., 2008). These weighty cultural capital factors possibly contribute to the better performance of the English L2 learners on the higher-order reading comprehension items and benchmarks over the African languages L1 learners. The multilingual complexity of South Africa is further complicated by the influx of immigrants from the surrounding African countries. Providing learners from all sectors with quality English L2 instruction from an early age could counteract marginalisation within the South African society (McLeod Palane, 2017). Adequate home and school mediatory contexts are critical for every learner to develop their home language and further research is needed to provide better quality mother tongue support and instruction to learners. However, for many learners in South Africa an early immersion in English L2 with their L1 as a subject provides critical access to print material for the development of higherorder reading comprehension.

The complexity inherent in the debate of whether learners should rather receive instruction in English over an African language that is their home language requires much consideration. Many parents would prefer that schools offer instruction in English (Webb, 2002; De Wet, 2002). However, many schools are unable to support an English LoLT for reasons such as:

- The teachers not being equipped to instruct a class in English because they lack the prerequisite skills to teach English at an academic level (Uys et al., 2007).

- Teachers having insufficient English L2 instructional resources (Uys et al., 2007). 
- The community within which the school is found does not support the learning of English as a second language and English becomes a foreign language for these learners and, as such, extremely difficult to master (Reeves et al., 2008).

However, the availability of resources in a home language will also affect learners whose LoLT is the L1 where the L1 is an African language. Lack of educational materials in African languages may cause parents to move their children to the better resourced English-medium state schools (Webb, 2002; Reeves et al., 2008). The lack of print material in all the home languages in equal quality and quantity suggests that mother tongue education in every African language, as blanket policy for every context, will not provide the best opportunity for every learner.

While access to home language instruction remains the right of every learner, equal opportunity should be an important consideration in every context. Building English L2 instructional capacity for all learners (whether as the language of instruction or as a subject) from the start of formal schooling, and even before in Early Childhood Education, needs to be carefully considered as a means of facilitating equal learning opportunities.

This means research is required into how instruction in the classroom might be adapted for teaching the L1 or L2 learner. Further research is required into how to support South African teachers in providing better home language instruction, coupled with focused English L2 instruction, from the start of school.

An amplification of focus needs to be on improving English L2 instruction. It is possible that early immersion in English L2 with strong support for home language learning can be a vehicle for across the board quality educational provision.

\section{References}

Analyzer, I.D.B. 2012. Computer software and manual. Hamburg, Germany: International Association for the Evaluation of Educational Achievement.

Banda, F. 2000. The dilemma of the mother tongue: Prospects for bilingual education in South Africa. Language Culture and Curriculum, 13(1), 51-66. https://doi. org/10.1080/07908310008666589

Banda, F. 2009. Critical perspectives on language planning and policy in Africa: Accounting for the notion of multilingualism. Stellenbosch Papers in Linguistics PLUS, 38(1), 1-11. https:// doi.org/10.5842/38-0-50

Bandura, A. 2001. Social cognitive theory: An argentic perspective. Annual Review of Psychology, 52(1), 1-26. https://doi.org/10.1146/annurev.psych.52.1.1

Bourdieu, P. 1986. The forms of capital. In J. Richardson (Ed.) Handbook of theory and research for the sociology of education. New York: Greenwood.

Bruner, J.S. 1966. Toward a theory of instruction (vol. 59). Harvard University Press.

Corp, I.B.M. 2012. IBM SPSS statistics for windows, version 23.0.

Cummins, J. 1979. Linguistic interdependence and the educational development of bilingual children. Review of Educational Research, 49(2), 222-251. https://doi. org/10.3102/00346543049002222 
Cummins, J., 1992. Bilingual education and English immersion: The Ramirez report in theoretical perspective. Bilingual Research Journal, 16(1-2), 91-104. https://doi.org/10.108 0/15235882.1992.10162630

Cummins, J. 2000. Language, power, and pedagogy: Bilingual children in the crossfire (23). Multilingual Matters. https://doi.org/10.21832/9781853596773

De Wet, C. 2002. Factors influencing the choice of English as language of learning and teaching (LoLT)-a South African perspective. South African Journal of Education, 22(2), 119-124.

Department of Basic Education (DBE). 2010. Status of the language of learning and teaching (LOLT) in South African public schools. Pretoria: DBE.

Evans, R. \& Cleghorn, A. 2014. Parental perceptions: A case study of school choice amidst language waves. South African Journal of Education, 34(2), 1-19. https://doi. org/10.15700/201412071203

Field, A. 2009. Discovering statistics using SPSS. Sage publications.

Howie, S.J., van Staden, S., Tshele, M., Dowse, C. \& Zimmerman, L. 2012. South African children's reading literacy achievement summary report. Pretoria: Centre for Evaluation and Assessment.

Martin, M.O. \& Mullis, I.V.S. (Eds.). 2012. Methods and procedures in IMSS and PIRLS 2011. Chestnut Hill, MA: TIMSS \& PIRLS International Study Center.

McLeod Palane, 2017. The effect of language of instruction and contextual factors on higherorder reading comprehension performance. Doctoral dissertation. Pretoria: University of Pretoria.

Mullis, I.V. 2007. PIRLS 2006 international report: IEA's progress in international reading literacy study in primary schools in 40 countries. Chestnut Hill, MA: TIMSS \& PIRLS International Study Center.

Posel, D. \& Casale, D. 2011. Language proficiency and language policy in South Africa: Findings from new data. International Journal of Educational Development, 31(5), 449-457. https://doi.org/10.1016/j.ijedudev.2010.09.003

Pretorius, E.J. 2014. Supporting transition or playing catch-up in Grade 4? Implications for standards in education and training. Perspectives in Education, 32(1), 51-76.

Pretorius, E.J. \& Mampuru, D.M., 2007. Playing football without a ball: language, reading and academic performance in a high-poverty school. Journal of Research in Reading, 30(1), 38-58. https://doi.org/10.1111/j.1467-9817.2006.00333.x

Probyn, M. 2009. 'Smuggling the vernacular into the classroom': conflicts and tensions in classroom codeswitching in township/rural schools in South Africa. International Journal of Bilingual Education and Bilingualism, 12(2), 123-136. https://doi. org/10.1080/13670050802153137

Reeves, C., Heugh, K., Prinsloo, C. H., Macdonald, C., Netshitangani, T., Alidou, H., Diedericks, G. \& Herbst, D. 2008. Evaluation of literacy teaching in primary schools of Limpopo province. Commissioned by the Limpopo Department of Education (LDoE). HSRC in Association with the Department of Language Education at the University of Limpopo. 
Taylor, S. \& Coetzee, M. 2013. Estimating the impact of language instruction in South African primary schools: a fixed effects approach (21/13). Stellenbosch Economic Working Papers. Stellenbosch.

Uys, M., Van der Walt, J., Van den Berg, R. \& Botha, S. 2007. English medium of instruction: A situation analysis. South African Journal of Education, 27(1), 69-82.

Vygotsky, L. 1978. Mind and society: The development of higher mental processes. Cambridge, M.A: Harvard University Press.

Webb, V.N. 2002. April. Language policy development in South Africa. In World Congress on Language Policies, Barcelona, Spain. https://doi.org/10.1075/impact.14

Woolman, S. \& Fleisch, B., 2006. South Africa's education legislation, quasi-markets and de facto school choice. Perspectives in Education, 24(2), 1-24.

Zimmerman, L. 2010. The influence of schooling conditions and teaching practices on curriculum implementation for Grade 4 reading literacy development. Doctoral dissertation. Pretoria: University of Pretoria. 